\title{
Effect of Neighbourhood Characteristics on Resident's Satisfaction in Doya Area of Bauchi Metropolis
}

\author{
Hadiza AbdulKadir Musa ${ }^{1}$, Muhammad Umar Bello ${ }^{2}$, Sakariyau Jamiu Kayode ${ }^{2}$ \\ ${ }^{1}$ Kaduna Polytechnic \\ Polytechnic Road, P. M. B. 2021, Kaduna, Nigeria \\ ${ }^{2}$ Abubakar Tafawa Balewa University \\ Tafawa Balewa Way, P. M. B. 0248, Bauchi, 740272, Nigeria
}

DOI: $10.22178 /$ pos.69-8

JEL Classification: 018

Received 20.03.2021

Accepted 28.04.2021

Published online 30.04.2021

Corresponding Author:

Sakariyau Jamiu Kayode

jamiuem@gmail.com

(C) 2021 The Authors. This article

is licensed under a Creative

Commons Attribution 4.0

License @ (1)

\begin{abstract}
This study determines the effect of neighbourhood characteristics on residents' satisfaction in Doya area of Bauchi metropolis to reveal the significant relationship of the effect. Field data were gathered using a structured, close-ended questionnaire containing 5 Likert scales administered to the household head of Doya area of Bauchi metropolis using simple random sampling. A total number of one hundred and twenty-five (125) valid questionnaires were used for the analysis. The data were analyzed using descriptive statistics (Mean score and frequency table) and linear regression method through SPSS. The study found that electricity, water, drainage, availability of schools, availability of hospital, economic activities, neighbourhood security, sanitary services, recreational facilities and accessibility are factors affecting resident's satisfaction. It further found that satisfaction with proximity to work, water, and educational facilities were striking the highest mean score. Finally linear regression model reveals that neighbourhood condition significantly affects resident's satisfaction. The study suggests a need for the government to provide more social amenities in the study area. Proper routine management of social amenities should be done to enhance the resident's satisfaction in the study area.
\end{abstract}

Keywords: neighbourhood; satisfaction; housing.

\section{INTRODUCTION}

Housing is considered a basic need and a necessity for man's existence. Thus, it's one of the most critical basic infrastructures in the development of every society [3]. Also, [1] admits that housing is one of the three basic needs of humanity. Its performance should meet technical expectations as well as the overall satisfaction of end-users. Housing touches the lives of individuals and the nation; great importance is therefore ascribed to its role in engendering human comfort by nature and society $[3,7]$. Authors [1] stated that one of the basic needs of man is shelter. The right to adequate housing is a universal right, recognized at the international level and in more than one hundred national constitutions worldwide. Despite this right, the 'homeless', 'the inadequately housed', and 'the evicted' are numerous in the cities and the countryside across the globe.
Residents' satisfaction refers to the degree of satisfaction felt about the environmental amenities available in different aspects of a residential environment. Information on residents' satisfaction has become a handy tool in the hands of housing developers, analysts, and policymakers for a long time now [4]. Residential satisfaction reflects the degree to which individuals' housing needs are fulfilled [8]. According to [6], residential satisfaction refers to the degree of contentment experienced by a household regarding the current housing situation. It is a non-economic and normative quality evaluation approach to assess the quality of housing units.

Neighbourhoods are defined as residences and the physical, social, and economic circumstances that affect these residences [2]. They are places where people live their daily lives - places where people go for a walk with their pets, where par- 
ents spend time with their kids at a playground, where neighbours have a chat at a park, and seniors grow vegetables in a nearby garden. Neighbourhoods are meaningful to people, so magazines feature neighbourhoods and report on their amenities and the personalities of their residents. Residential environment quality and satisfaction are among the primary conditions for quality of life and the main support for economic activities, culture, and society. The importance of the neighbourhood environment to urban dwellers cannot be overemphasized; it remains the most fundamental basis of life because where people live or spend most of their lives affect their economic, social, health, and mental well-being. Due to the diversity of personal senses of looking at things and the varied lifestyles, people's demands, preferences and evaluations of their neighbourhood environment are equally becoming more diversified [5].

Resident's satisfaction can be affected by many factors; one of these factors can be neighbourhood condition. The effect of neighbourhood condition on residential satisfaction can be positively or negatively; when social amenities or infrastructural facilities are good, the satisfaction was significantly excellent and vice versa. Most people in developing countries still lack the necessities of life such as shelter, health facilities, a good road network, portable water, regular supply of electricity, to mention but a few. The lack of these basic needs of life by many could be attributed to poor management of public funds by leaders, lack of adequate workforce to harness the resources available, political instability and lack planning by local authorities [9]. Hence the gap in the literature is identified; therefore, this paper will attempt to address issues on the effect of neighbourhood characteristic on resident's satisfaction in Doya area of the Bauchi metropolis.

This study aims to determine the effect of neighbourhood characteristics on residents' satisfaction in Doya area of Bauchi metropolis to reveal the significant relationship between neighbourhood conditions and residents' satisfaction.

Objectives:

1. To identify the neighbourhood characteristics in the study area.

2. To examine the level of resident' satisfaction in the study area.
3. To assess the effect of neighbourhood characteristics on resident' satisfaction in the study area

A field survey research approach was adopted for the study. Data were collected using a soundstructured questionnaire containing close-ended questions (for ease of analysis). The questionnaire was designed for the household head living in the study area using a five-point Likert scale. A total of two hundred (200) copies of the questionnaires were administered to randomly selected residents within the study area. Out of the 200 questionnaires administered, 125 valid copies were filled and retrieved. Mean ranking was used to measure the degree of neighbourhood characteristics and resident's satisfaction. At the same time, linear regression was also used to determine the effect of the neighbourhood characteristic on residents' satisfaction.

\section{RESULTS AND DISCUSSIONS}

Table1 - Demographic Data of the Respondents

\begin{tabular}{|c|c|c|}
\hline & $\mathrm{N}$ & $\%$ \\
\hline \multicolumn{3}{|c|}{ Gender } \\
\hline Male & 96 & 76.2 \\
\hline Female & 30 & 23.8 \\
\hline \multicolumn{3}{|c|}{ Age } \\
\hline Less than30 years & 58 & 46.0 \\
\hline between 31-40 years & 30 & 23.8 \\
\hline between $41-50$ years & 24 & 19.0 \\
\hline above 50 years & 14 & 11.2 \\
\hline \multicolumn{3}{|c|}{ Marital status } \\
\hline Single & 51 & 40.5 \\
\hline Married & 75 & 59.5 \\
\hline \multicolumn{3}{|c|}{ Education } \\
\hline Primary school & 24 & 19.0 \\
\hline O level & 39 & 31.0 \\
\hline OND/NCE & 42 & 33.3 \\
\hline HND & 12 & 9.5 \\
\hline BSC & 7 & 5.6 \\
\hline MSC & 1 & 0.8 \\
\hline PHD & 1 & 0.8 \\
\hline \multicolumn{3}{|c|}{ Occupation } \\
\hline Farming & 26 & 20.6 \\
\hline Retired & 36 & 28.6 \\
\hline Artisan & 18 & 14.3 \\
\hline Private Sector & 22 & 17.5 \\
\hline Public Sector & 24 & 19.0 \\
\hline \multicolumn{3}{|c|}{ Tenure ship } \\
\hline Occupier & 95 & 75.4 \\
\hline Renting & 31 & 24.6 \\
\hline
\end{tabular}


The table above shows the demographic data of the respondents. It reveals that most households are male and married couples as it represents $76.2 \%$ and $59.5 \%$ of the responses. Also, most of them are within the age group of less than 30years and 31-40 years. Furthermore, it's found that majorities are farmers/retired workers, and they are NCE/OND holders. Finally, it is concluded that most of them are owner-occupiers which represent $75.4 \%$ of the responses.

Table 2 - Ranking Neighbourhood Condition / Characteristics

\begin{tabular}{|l|c|c|c|c|}
\hline \multicolumn{1}{|c|}{ Items } & $\mathrm{N}$ & Mean & $\begin{array}{c}\text { Std. } \\
\text { Deviation }\end{array}$ & Remark \\
\hline $\begin{array}{l}\text { Ranking electric } \\
\text { condition in the } \\
\text { area }\end{array}$ & 125 & 3.80 & .762 & 1 \\
\hline $\begin{array}{l}\text { Ranking water } \\
\text { condition in the } \\
\text { area }\end{array}$ & 125 & 3.75 & .973 & 2 \\
\hline $\begin{array}{l}\text { The ranking } \\
\text { drainage } \\
\text { condition in the } \\
\text { area }\end{array}$ & 125 & 3.41 & 1.277 & 3 \\
\hline $\begin{array}{l}\text { Ranking } \\
\text { recreational } \\
\text { facilities } \\
\text { condition in the } \\
\text { area }\end{array}$ & 125 & 2.95 & 1.396 & 4 \\
\hline $\begin{array}{l}\text { Ranking } \\
\text { accessibility / } \\
\text { road condition in } \\
\text { the area }\end{array}$ & 125 & 2.94 & 1.220 & 5 \\
\hline $\begin{array}{l}\text { Ranking sanitary } \\
\text { service condition } \\
\text { in the area }\end{array}$ & 125 & 2.85 & 1.251 & 6 \\
\hline $\begin{array}{l}\text { Ranking schools' } \\
\text { condition in the } \\
\text { area }\end{array}$ & 125 & 2.83 & 1.366 & 7 \\
\hline $\begin{array}{l}\text { Ranking } \\
\text { economic } \\
\text { activities } \\
\text { condition in the } \\
\text { area }\end{array}$ & 125 & 2.71 & .974 & \\
\hline $\begin{array}{l}\text { Ranking } \\
\text { hospitals } \\
\text { condition in the } \\
\text { area }\end{array}$ & 125 & 2.60 & 1.225 & \\
\hline $\begin{array}{l}\text { Ranking } \\
\text { neighbourhood }\end{array}$ & & & & \\
\hline
\end{tabular}

Table 2 above shows the neighbourhood condition according to their mean ranking. It reveals that the electricity condition is in good condition with a mean of 3.80, which has the first rank, water condition is also found to be good as it has a mean of 3.75 which has the second rank. At the same time, health facilities and neighbourhood were and found to be moderate with east mean rank both.

Table 3 - Ranking Residents Satisfaction

\begin{tabular}{|l|c|c|c|c|}
\hline \multicolumn{1}{|c|}{ Items } & $\mathrm{N}$ & Mean & $\begin{array}{c}\text { Std. } \\
\text { Deviation }\end{array}$ & Remark \\
\hline $\begin{array}{l}\text { Satisfaction for } \\
\text { proximity to the } \\
\text { place of work }\end{array}$ & 125 & 3.59 & 1.115 & 1 \\
\hline $\begin{array}{l}\text { Water satisfaction in } \\
\text { the area }\end{array}$ & 125 & 3.58 & 1.079 & 2 \\
\hline $\begin{array}{l}\text { Satisfaction for the } \\
\text { availability of } \\
\text { educational facilities }\end{array}$ & 125 & 3.05 & 1.099 & 3 \\
\hline $\begin{array}{l}\text { Electricity } \\
\text { satisfaction in the } \\
\text { area }\end{array}$ & 125 & 2.91 & .942 & 4 \\
\hline $\begin{array}{l}\text { Satisfaction with } \\
\text { respect to } \\
\text { infrastructure / } \\
\text { services }\end{array}$ & 125 & 2.90 & .990 & 5 \\
\hline $\begin{array}{l}\text { Satisfaction for } \\
\text { political activities in } \\
\text { the area }\end{array}$ & 125 & 2.82 & 1.277 & 6 \\
\hline $\begin{array}{l}\text { Satisfaction with } \\
\text { respect to economic } \\
\text { activities }\end{array}$ & 125 & 2.67 & 1.162 & 7 \\
\hline $\begin{array}{l}\text { Satisfaction for the } \\
\text { proximity of the } \\
\text { place of worship }\end{array}$ & 124 & 2.67 & 1.181 & 8 \\
\hline $\begin{array}{l}\text { Satisfaction for } \\
\text { neighbourhood } \\
\text { security }\end{array}$ & 125 & 2.59 & 1.048 & 9 \\
\hline $\begin{array}{l}\text { Satisfaction with } \\
\text { respect to } \\
\text { recreational facilities }\end{array}$ & 2.39 & .999 & 10 \\
\hline
\end{tabular}

The table above shows the households satisfaction within the neighbourhood for their mean ranking. It admits that proximity to the place of work, water and educational facilities has the first, second and third satisfaction with a mean score 4.58, 3.58 and 3.05 respectively While satisfaction to the proximity of worship places, neighbourhood security and recreational facilities has a mean rank of 8,9 and 10 respectively. 
Table 4 - Model Summary

\begin{tabular}{|c|c|c|c|c|}
\hline Model & $\mathrm{R}$ & $\mathrm{R}^{2}$ & Adjusted $\mathrm{R}^{2}$ & $\begin{array}{c}\text { Std. Error of } \\
\text { the }\end{array}$ \\
\hline & & & & Estimate \\
\hline 1 & $.723 \mathrm{a}$ & .523 & .481 & .37384 \\
\hline
\end{tabular}

The $\mathrm{R}^{2}$ value in the model summary table above tells you how much of the variance in the dependent variable (resident's satisfaction in the study area) is explained by the model (which includes neighbourhood characteristics). This means that the model explains $52.3 \%$ of the variance in residents' satisfaction in the study area.

Table 5 shows the statistical significance of the analysis. The table shows a highly significant value of ".000", which is less than .05 (which means $\mathrm{p}<.0005)$. This means that the regression is suitable and fit well for the analysis.
Table 5 - ANOVA

\begin{tabular}{|l|l|l|l|}
\hline Df & Mean Square & F & Sig. \\
\hline 10 & 1.744 & 12.476 & $.000 \mathrm{~b}$ \\
\hline 114 & .140 & & \\
\hline 124 & & & \\
\hline
\end{tabular}

Table 6 shows the significant effect between neighbourhood characteristic and resident's satisfaction. Water, educational facilities, Drainage, Electricity, Recreational Facilities, sanitary services and health facilities, were the neighbourhood characteristic which significantly affects resident satisfaction which has a Beta value of $.298, .303, .179, .170, .149,-.134$ and .139 with $p$ value of both $.000, .000, .014, .024, .031, .055$ and .065 respectively.

Table 6 - Coefficient Table (model 1)

\begin{tabular}{|c|c|c|c|c|c|}
\hline & \multicolumn{2}{|c|}{$\begin{array}{c}\text { Unstandardized } \\
\text { Coefficients }\end{array}$} & \multirow{2}{*}{$\begin{array}{c}\begin{array}{c}\text { Standardized } \\
\text { Coefficients }\end{array} \\
\text { Beta } \\
\end{array}$} & \multirow[t]{2}{*}{$\mathrm{t}$} & \multirow[t]{2}{*}{ Sig. } \\
\hline & $\mathrm{B}$ & Std. Error & & & \\
\hline (Constant) & .943 & .228 & & 4.130 & .000 \\
\hline Ranking electric condition in the area & .116 & .050 & .170 & 2.295 & .024 \\
\hline Ranking water condition in the area & .159 & .040 & .298 & 3.949 & .000 \\
\hline Ranking drainage condition in the area & .073 & .029 & .179 & 2.483 & .014 \\
\hline $\begin{array}{l}\text { Ranking educational facilities condition in } \\
\text { the area }\end{array}$ & .115 & .029 & .303 & 4.024 & .000 \\
\hline Ranking hospitals condition in the area & .059 & .032 & .139 & 1.860 & .065 \\
\hline $\begin{array}{l}\text { Ranking recreational facilities condition in } \\
\text { the area }\end{array}$ & .056 & .025 & .149 & 2.188 & .031 \\
\hline $\begin{array}{l}\text { Ranking economic activities condition in the } \\
\text { area }\end{array}$ & .012 & .036 & .022 & .327 & .744 \\
\hline $\begin{array}{l}\text { Ranking neighbourhood security condition in } \\
\text { the area }\end{array}$ & .020 & .035 & .043 & .585 & .560 \\
\hline $\begin{array}{l}\text { Ranking sanitary service condition in the } \\
\text { area }\end{array}$ & -.056 & .029 & -.134 & -1.943 & .055 \\
\hline $\begin{array}{l}\text { Ranking accessibility/road condition in the } \\
\text { area }\end{array}$ & .042 & .029 & .100 & 1.443 & .152 \\
\hline
\end{tabular}

In contrast, accessibility, neighbourhood security and economic have a Beta value of .100, .043, and .022 with a p-value of $.152, .560$ and .744 , respectively, were found to have a less significant impact. So, this concludes that Water, educational facilities, Drainage, Electricity and Recreational Facilities were the neighbourhood characteristic which significantly affects resident's satisfaction with sanitary services to have a negative effect.

\section{CONCLUSION}

The initial analysis and discussion clearly show that neighbourhood characteristics and residents' satisfaction were analyzed using Statistical Package for Social Science (SPSS). The analysis is based on regression and means score ranking, which reveals that electricity condition, water condition, drainage condition, availability of schools, health facilities, recreational facilities, economic activities, neighbourhood security, sanitary services and accessibility affect housing sat- 
isfaction. Furthermore, it reveals that neighbourhood characteristics/condition significantly affect resident's satisfaction in the study area.

Since neighbourhood conditions affect resident satisfaction, the government needs to provide more social amenities to promote residential satisfaction. As most of the households within the neighbourhood agreed that they have poor secu- rity, there is a need for the government or policymakers to provide better policies to help the area be more secure.

Proper routine management of social amenities should be put in place to ensure good neighbourhood condition and the resident's satisfaction in the study area.

\section{REFERENCES}

1. Ayarkwa, J., Acheampong, A., \& Agyekum, K. (2013). Residents' Satisfaction with the Social Security and National Insurance Trust Housing in Ghana. Engineering Management Research, 2(2). doi: 10.5539/emr.v2n2p29

2. Baesung, K. (2013). The effect of neighborhood built environment on neighborhood satisfaction (Master's thesis); Georgetown University. Washington.

3. Bank of Ghana. (2007). The Housing Industry in Ghana: Prospects and Challenge. Retrieved from https://www.bog.gov.gh/wp-content/uploads/2019/07/pbrief-housing-new.pdf

4. Galster, G. (1987). Identifying the Correlates of Dwelling Satisfaction. Environment and Behavior, 19(5), 539-568. doi: 10.1177/0013916587195001

5. Ge, J., \& Hokao, K. (2006). Research on residential lifestyles in Japanese cities from the viewpoints of residential preference, residential choice and residential satisfaction. Landscape and Urban Planning, 78(3), 165-178. doi: 10.1016/j.landurbplan.2005.07.004

6. Ibem, E. O., \& Aduwo, E. B. (2013). Assessment of residential satisfaction in public housing in Ogun State, Nigeria. Habitat International, 40, 163-175. doi: 10.1016/j.habitatint.2013.04.001

7. Jiboye, A. D. (2010). Correlates of Public Housing in Lagos, Nigeria. Journal of Geography and Regional Planning, 3(2), 17-28.

8. Nyaboe, Sh. (2016). An assessment of residential neighbourhood satisfaction: a case of Bahati estate, Eastlands, Nairobi, Kenya. Retrieved from https://www.researchgate.net/publication/348975819_AN_ASSESSMENT_OF_RESIDENTIAL_N EIGHBOURHOOD_SATISFACTION_A_CASE_OF_BAHATI_ESTATE_EASTLANDS_NAIROBI_KENYA

9. Rashid, S. T., bin Ngah, I., \& Eluwa, S. E. (2013). Neighbourhood choice factors and residents satisfaction in old and new neighbourhoods of Slemani City, Kurdistan-Iraq. Journal of Environment and Earth Science, 3(2), 72-81. 